\title{
Evaluation of Larvicidal Efficacy of Aloe Vera Extract against Musca Domestica
}

\author{
Jesikha. M, \\ $P G$ and Research Department of Zoology, Kongunadu Arts and Science College, Coimbatore 29, Tamilnadu.
}

\begin{abstract}
In the present study, crude extract of Aloe vera have been screened for their larvicidal activity against Musca domestica. All the three instars larvae of housefly were treated with the different concentrations by dipping method for 24 and $48 \mathrm{hrs}$. The $L C_{50}$ values of Aloe vera extract were found to be 32.67, 36 and 38.67 ppm in $24 \mathrm{hrs} ; 24,25.67$ and $28.33 \mathrm{ppm}$ in $48 \mathrm{hrs}$ on $1^{\text {st }}, 2^{\text {nd }}$ and $3^{\text {rd }}$ instars respectively. The crude extract of Aloe vera was found to be more active in terms of larvicidal potential.
\end{abstract}

Key words: Aloe vera, instars, Musca domestica, larvicidal

\section{Introduction}

The order Dipetra presents an array of insects which more than any other group poses the greatest challenge to human and veterinary health as vectors of diseases. One such insects, which share a close ecological niche with man is the housefly, Musca domestica. Apart from disease transmission, M. domestica soils man's food and usually constitutes a nuisance, particularly the adult stage [1]. House flies feed on liquid or semi-liquid substances beside solid material which has been softened by saliva or vomit. Because of their high intake of food, they deposit feces constantly, one of the factors that make the insect a dangerous carrier of pathogens. Musca domestica causes a serious threat to human and livestock health by transmitting many infectious diseases. In view of the severity of the problem, it is imperative that control of houseflies must be improved through the application of occupationally and environmentally safe natural pesticides [2]. Because of the safety to insect parasites, predators and other non-target organisms, low mammalian toxicity and short persistence in the environment as compared to the synthetic insecticides, many investigators recommended the use of plant extracts as pest control agents [3\&4].

Aloe vera gel is used as an ingredient in commercially available lotion, yogurt, beverages, and some desserts. Aloe vera extracts have antibacterial and antifungal activities, which may help in the treatment of minor skin infections, such as boils and benign skin cysts and have been shown to inhibit the growth of fungi that cause tinea [5]. For bacteria, inner-leaf gel from aloe vera was shown to inhibit growth of Streptococcus and Shigella species in vitro [6]. In contrast, aloe vera extracts failed to show antibiotic properties against Xanthomonas species [7]. It has also been suggested that biofuels could be obtained from Aloe vera seeds.It is common practice for cosmetic companies to add sap or other derivatives from Aloe vera to products. Aloe vera has a long association with herbal medicine. Aloe vera may be effective in treatment of wounds [8].

The present paper deals with the possible effects of the plant Aloe vera extract, in larval treatments on this house fly, which is a serious pest for the animal and human health.

\section{Materials And Methods}

Exctract of Aloe vera was collected by cuttings of leaf part. Different concentrations 20, 40, 60, 80 and $100 \mathrm{ppm}$ were made with water. Twenty number of $1^{\text {st }}, 2^{\text {nd }}$ and $3^{\text {rd }}$ instar larvae of $M$. domestica were selected separately for each set of treatment. Five numbers of glass beakers of $250 \mathrm{ml}$ capacity were taken and labeled for different concentrations in addition to one for control. Larvae were treated by dipping method as explained Begum (Begum et al., 2010). Each experiment was conducted in triplicates along with the control group. Mortality of larvae followed by the exposure was recorded in $24 \mathrm{hrs}$ and $48 \mathrm{hrs}$. $\mathrm{LC}_{50}$ was calculated using Karber's method [9].

\section{Results And Disscusion}

The results presented in (Fig no: 1 and 2) exhibit the toxicity of exctract of Aloe vera against $1^{\text {st }}, 2^{\text {nd }}$ and $3^{\text {rd }}$ instar larvae of $M$. domestica, in 24 and $48 \mathrm{hrs}$ with different concentration. The treatment of three instars larvae of $M$. domestica with different concentrations of the extracts of exhibited relatively lower percent mortality after shorter duration (24hrs) than that at longer duration (48hrs). Aloe vera leaves contain a range of biologically active compounds, the best-studied being acetylated mannans, polymannans, anthraquinone Cglycosides, anthrones and anthraquinones, and various lectins [10\& 11]. The extract was found to be quite effective against $M$. domestica larvae as $100 \%$ mortality was observed at $100 \mathrm{ppm}$ in all the three instars The $\mathrm{LC}_{50}$ of $1^{\mathrm{st}}$ instar was $32.67 \mathrm{ppm}$ at $24 \mathrm{hrs}$ short duration and $24 \mathrm{ppm}$ at $48 \mathrm{hrs}$ long duration. The $1^{\text {st }}$ instar was 
sensitive then $2^{\text {nd }}$ instar and the $2^{\text {nd }}$ instar was sensitive compare then $3^{\text {rd }}$ instar larvae. In this study it was proved. The $\mathrm{LC}_{50}$ of $2^{\text {nd }}$ instar was $36 \mathrm{ppm}$ at short duration and $25.67 \mathrm{ppm}$ at longer duration. The longer duration exhibited high mortality percentage in lower concentration. The $\mathrm{LC}_{50}$ of $3^{\text {rd }}$ instar was $38.67 \mathrm{ppm}$ and $28.33 \mathrm{ppm}$ at $24 \mathrm{hrs}$ and $48 \mathrm{hrs}$ respectively. Compare to control all the stages shows singnifigant mortality percentage against Aloe vera extract.

The medical and veterinary pest Musca domestica $\mathrm{L}$. has developed resistance to most insecticides used against it. For this reason, there is a constant search for new alternative control tools [12, 13 \& 14]. Plant products become more interesting. Many plants have been reported about their potential insecticidal actions on larvae and/or adults of house flies via crude extracts or extracted active compounds [15]. Extracts from the Azadirachta indica A. (Juss, Meliaceae) seeds [16], leaves of Acalypha indica, Carica papaya and Santalum album [17] were also tested in the same insects musca domestica as insecticidal agents.

Calotropis gigantica gave the highest larval retention activity and it increased with leaf extract concentration. Peganum harmala powder prolonged the larval duration, hindered larval/pupal transformation and incomplete emergence of imago from puparia as reported by Ahmed et al., [18]. Successful or complete adult emergence rates were consistently lower with all plant based diets than with control experiment at leaf concentration [17].

\section{Tables And Figures}

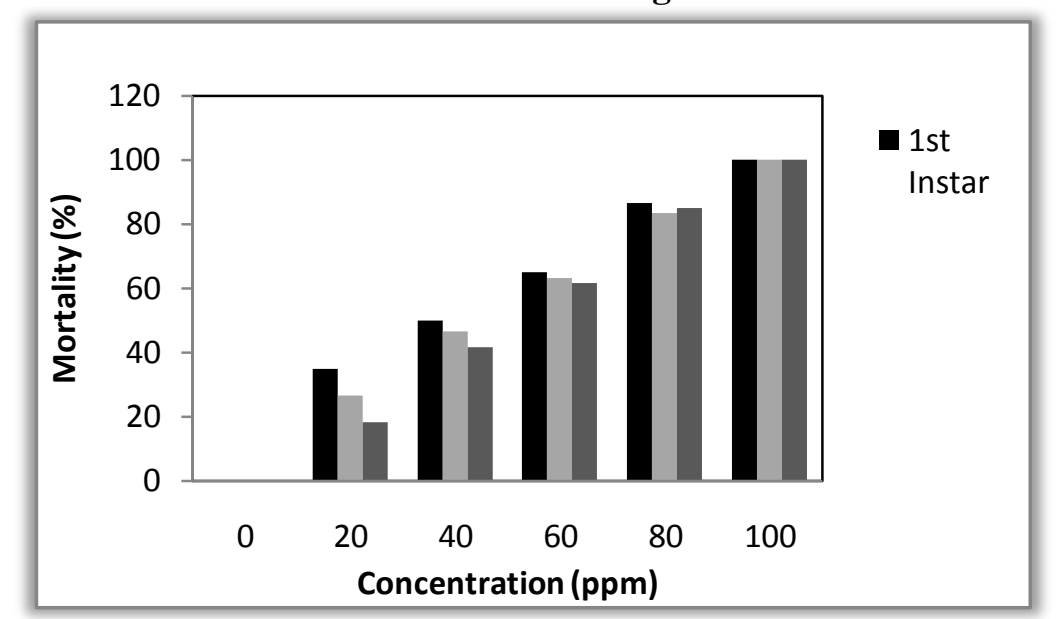

Figure 1: Mortality of larvae on Aloe vera extract at different concentration for 24hrs

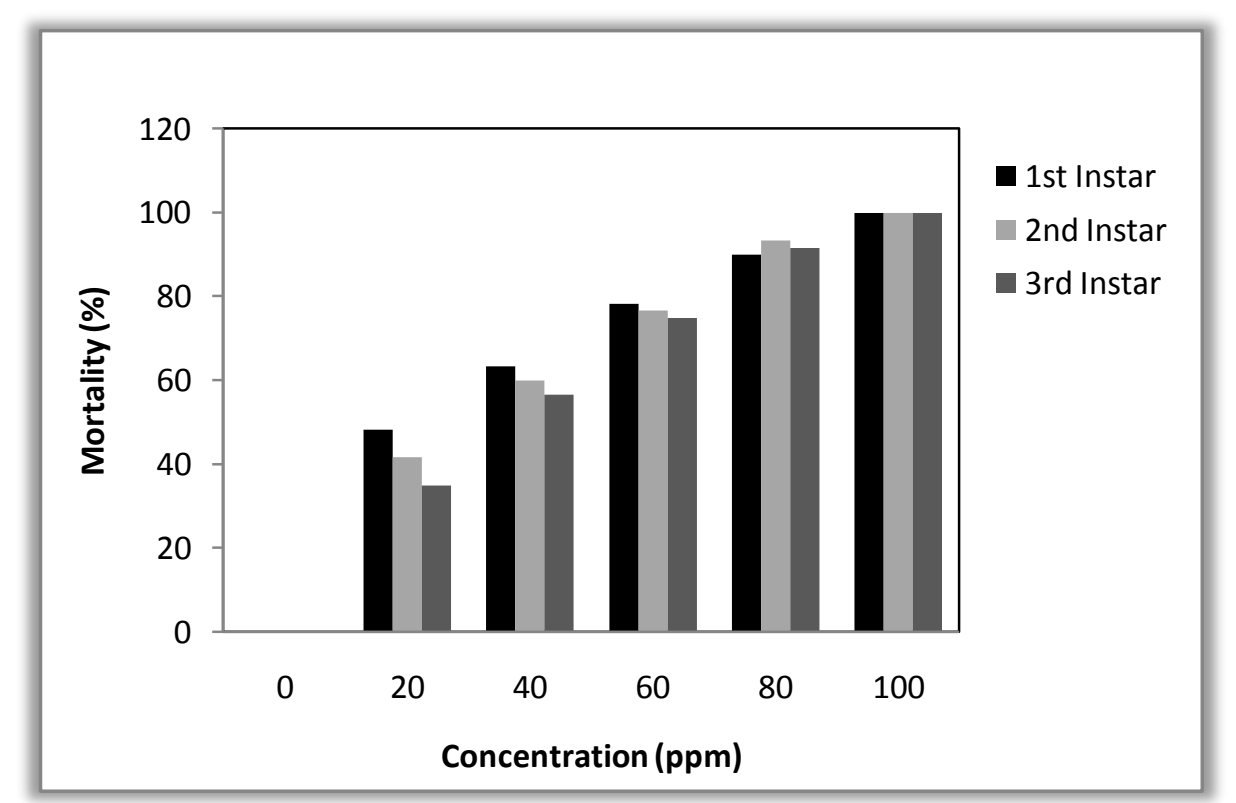

Figure 2: Mortality of larvae on Aloe vera extract at different concentration for $48 \mathrm{hrs}$ 


\section{Reference}

[1] Boushy and A. R. El, Housefly pupae as poultry manure converters for animal feed: A review, Bioresource technology 38 , 1991 , 45 -49 .

[2] M. F. Khan, S. M. Ahmed, Toxicity of Crude Neem Leaf Extract Against Housefly Musca domestica L. Adults as Compared With DDVP, Dichlorvos. urk J Zool. 4, 2000, 219-223.

[3] S. S. Nathan, K. Kalaivani and K. Murugan, Effects of neem limonoids on the malaria vectors Anopheles stephensi Liston (Diptera: Culicidae). Acta Trop., 96, 2005, 47-55.

[4] P. T. Deota and P.R. Upadhyay, Biological studies of azadirachtin and its derivatives against polyphagous pest, Spodoptera litura, Nat. Prod. Res., 19, 2005, 529-39.

[5] S. Shamim, S. Ahmed, Waseemuddin and Azhar Iqbal, Antifungal activity of Allium, Aloe, and Solanum species". Pharmaceutical Biology 42 (7), 2004, 491-498.

[6] V.A. Ferro, F. Bradbury, P. Cameron, E. Shakir, S. R. Rahman and W. H. Stimson, In vitro susceptibilities of Shigella flexneri and Streptococcus pyogenes to inner gel of Aloe barbadensis Miller, Antimicrobial agents and chemotherapy, 47 (3), $2003,1137-9$.

[7] S. Satish, K. A. Raveesha and G. R. Janardhana, Antibacterial activity of plant extracts on phytopathogenic Xanthomonas campestris pathovars". Letters in Applied Microbiology 28 (2), 1999, 145-147.

[8] B. K. Vogler and E. Ernst, Aloe vera: a systematic review of its clinical effectiveness, The British journal of general practice : the journal of the Royal College of General Practitioners 49 (447), 1999, 823-828.

[9] G. Karber, Beitrag zur kollektiven Behandlung pharmakologischer Reihenversuche. Arch. für Experimentelle Pathologie und Pharmakologie 162, 1931, 480-483.

[10] G. K. King, K. M. Yates and P. G. Greenle, The effect of Acemannan Immunostimulant in combination with surgery and radiation therapy on spontaneous canine and feline fibrosarcomas, Journal of the American Animal Hospital Association 31 (5), 1995, 439447.

[11] K. Eshun and Q. He, Aloe vera: a valuable ingredient for the food, pharmaceutical and cosmetic industries--a review, Critical reviews in food science and nutrition 44 (2), 2004, 91-96.

[12] E. S. Douglass and C. Jesse, Integrated pest management for fly control in Maine dairy farms, Texas Agricultural Extension Service, 4(6), 2002.

[13] G. Tarelli, E. N. Zerba and R. A. Alzogaray, Toxicity to vapor exposure and topical application of essential oils and monoterpenes on Musca domestica (Diptera: Muscidae). J. Econ. Entomol. 102 (3), 2009, 1383-1388.

[14] J. G. Huang, L. J. Zhou, H. H. Xu and W. O. Li, Insecticidal and cytotoxic activities of extracts of Cacalia tangutica and its two active ingredients against Musca domestica and Aedes albopictus. J. Econ. Entomol., 102(4), 2009, 1444- 1447

[15] H. Schmutterer, Properties and potential of natural pesticides from the neem tree Azadirachta indica. Ann, Rev, Entomol. 35, 1990, $271-297$.

[16] M. B. Isman, O. Koul, A. Lucznsk and J. Kaminski, Insecticidal and antifeedant bioactivies of neem oil and their relationship to azadirachtin, J. Agric. Food Chem., 38, 1990, 1406-1411

[17] A. T. Ande, Biological activities of some plant materials against the housefly - Musca domestica, NISEB Journal, Vol. 1, No 4, 2001, $293-296$.

[18] S. M. Ahmed, H. Chandler and J. Pereira, Insecticidal potentials and biological activity of Indian indigenous plants against Musca domestica L, Int. Pest Control 23(6), 1981, 170 - 175. 